„Ante Portas - Studia nad Bezpieczeństwem”

2019, $\mathrm{Nr} 1(12)$

DOI: $10.33674 / 220193$

Wiktor MOŻGIN ${ }^{1}$

Poland

\title{
STATE SECURITY AS AN ELEMENT OF NATIONAL CULTURE - THE PHENOMENON OF THE ALL-RUSSIAN MILITARY-PATRIOTIC MOVEMENT OF YUNARMIA
}

\begin{abstract}
:
Nowadays, the world is back in competition for influence on the international arena. The unipolar arrangement with the leading role of the United States, which was formed after the collapse of the Soviet Union, has been destroyed. Today, one of the countries that returns to the position of a superpower not only regional but also world-wide is the Russian Federation. The factor that testifies to the power of the Russian state is its military potential. In this context, the issue of human resources is an important aspect that deserves special attention. Russia treats the human factor as one of the priority elements of state development. Today, inside the Russian state, a pragmatic cultural tendency based on the idea of military-patriotic education of youth has been formed. In 2016, the all-Russian military-patriotic Yunarmia movement was created. On the scale of the Russian state, this is a phenomenon of security culture based on the education of patriotic attitudes and defence capabilities among the young generation of Russians. Yunarmia, through its direct connection with the Ministry of National Defence of the Russian Federation, provides a platform for the development of Russian military and thus the potential that translates into Russia's international power position.
\end{abstract}

Keywords:

Yunarmia, Russian Federation, culture of security, defence capabilities, military-patriotic education, military potential of the state.

\footnotetext{
${ }^{1}$ Wiktor Możgin, Master of Political Science at the Ignatianum Academy in Cracow, PhD student at the Jagiellonian University in Cracow (cultural studies). Email: viktor1990@wp.pl
} 


\section{Introduction}

The common denominator, which is also the main goal of every participant in international relations, is the issue of security. Contemporary researchers dealing with security issues argue that the scope of this concept is systematically expanding with the progress of civilization which intensified at the beginning of the 20th century. Social development was not only a sphere of mutual interactions but was also a determinant of the emergence of new threats. Janusz Stefanowicz referred to the issue of security in the context of civilization progress as a certain process during which the meaning of this concept was extended. Nowadays, it is not limited only to the scope of military security but it also covers non-military spheres - political, economic, cultural, ecological ${ }^{2}$. The fundamental goal, which so far consisted in guaranteeing the survival of the state as an entity on the international stage, was also redefined. It is today, above all, about ensuring the prosperity of this state and its citizens, the defence of freedom and identity, and, moreover, to prevent the dysfunctionality of the political system ${ }^{3}$. It is also worth paying attention to the fact that there is a direct relationship between the issue of state security and the international system in which it operates. Therefore, internal security depends largely on external security. Following this direction, it should be noted that the security of the state depends on its position in the system of international interactions.

The end of the 20th century was a period when the international system underwent radical changes. The disintegration of the Soviet Union, which for several decades was in an ideological, economic, military and cultural rivalry with the United States, heralded the advent of a new stage in the development of international relations. The bipolar system of the world was replaced by a unipolar system in which the American state began to play a decisive role

Many researchers in political, economic and cultural life have indicated that a system in which there is only one player who is not able to compete, and with this potential development, will not survive for too long. The euphoria prevailing in the Western world ended with the emergence of the thenreawakening potential of powers, which began to take control of individual regions. Fareed Zakaria at the beginning of the 21 st century pointed to the end of America's hegemony and the emergence of its potential rivals in the context of rivalry for control of the world ${ }^{4}$. Robert Kagan, in turn, stated that the peaceful order that was formed after the Cold War was replaced by a harsh

\footnotetext{
${ }^{2}$ J. Stefanowicz, Przedmowa, [w:] Wspótczesne pojmowanie bezpieczeństwa, red. J. Stańczyk, Warszawa 1996, pp. 6-8.

${ }^{3}$ Ibidem, pp. 7.

${ }^{4}$ F. Zakaria, Koniec hegemonii Ameryki, Warszawa 2009, pp. 12-16.
} 
reality in which great powers - Russia, China, Iran, India, Japan, Germany, or France - plunged into competition for influence ${ }^{5}$.

The implication of a change in the balance of power in the international arena was the redefinition of the notions of security and war. Nowadays, the traditional "clausewitzian" understanding of war has lost its significance. Today's war is carried out above all about the minds of society. The battlefield is no longer just a battlefield, but an informational and cultural sphere.

The redefinition of the concept of security in the context of a change in the balance of power on the international arena, which is dictated by the phenomenon of reviving powers, especially the Russian Federation, is the object of scientific discussion in many research centres around the world. The prospect of Russia's direct proximity to the region of Central and Eastern Europe creates the need for a broader analysis of security phenomena that currently occur within the Russian state. An interesting element of the defence system of the Russian Federation, which deserves attention, is the issue of the appointment in 2016 in accordance with the initiative of the Minister of National Defence of the Russian Federation, Sergey Shoygu, the all-Russian youth military-patriotic movement Yunarmia. Therefore, this youth movement is worth analysing, especially in the context of considerations regarding the aspect of security culture as an element of national security.

The resurgent post-Cold War rivalry between the United States and the Russian Federation is a consequence of the process of replacing the communist ideology with pragmatic Russian conservatism that has been taking shape in Russia since the early 1990s of the 20th century. It consists in creating a feeling of permanent competition with other countries on the international arena and a special role in this area of the Russian state. The conviction of the uniqueness of the Russian nation in the context of historical events (going beyond the Cold War rivalry) shapes the space of the basic narrative between the state and citizens in Russia. Creating the image of the Russian Federation as a state that has played an important role in the process of civilization development requires incorporation of its phenomenon into a cultural framework. The rationale behind this move is the fact that culture generally covers the non-material and material spheres (often referred to as the civilizational space of a given nation). Non-material culture covers a team of spiritual and intellectual accomplish-ments of man. Material, in turn, is the whole of the products of the nation, constituting its identity and, above all, its uniqueness in relations to other. Nowadays in Russia, based on the cultural context, the process of shaping the so-called culture of defence, especially among the young generation of Russians.

\footnotetext{
${ }^{5}$ R. Kagan, Powrót historii i koniec marzeń, Poznań 2010, pp. 27-29.
} 
In connection with this situation, the aim of this article is to present the process of shaping the Russian security culture among young people as part of broadly understood state security. The mentioned Yunarmia youth-patriotic movement is an exemplification of the phenomenon of strengthening the defence potential of the Russian Federation. Essentially, the discussion on this topic boils down to the question - what is the importance of culture and military-patriotic education in the context of the defence capabilities of the Russian state? Therefore, the article presents an analysis of the phenomenon of the Russian Yunarmia as a cultural aspect in the spatial area of national security. The methodology of the work was based on the examination of the organizational and organizational process of the Yunarmia as well as on the analysis of the trends within this youth-patriotic trend movement ${ }^{6}$.

\section{The All-Russia youth-patriotic movement of Yunarmia as part of the Russian security culture}

The research perspective based on the assumption that the phenomenon of broadly understood culture is a binder combining security and defence issues, will allow us to better understand the processes and phenomena constituting the basis of these considerations. A high level of security culture is the basis for anticipating potential threats from other participants in international relations and indicating the possibility of preventing crisis situations arising from this background.

In the literature, culture of security is defined as a characteristic of a particular entity way of thinking about security, feeling of security and ways to achieve security. The implication of this last aspect is the broadly understood issue of defence ${ }^{7}$. A more detailed definition of culture of security presents it as a model of basic assumptions, values, norms, rules, symbols and convictions characteristic for a given entity, which influence the way the subject perceives challenges, opportunities and threats in the near and distant surroundings, and the way you feel about security and thinking about it, and related behaviour and actions, in a different way by this entity learned and articulated, in the processes of broadly understood education, including also in the natural processes of internal integration and external adaptation and other organizational processes, as well as the process of strengthening broadly understood defence, serving the harmonious development of this entity

\footnotetext{
${ }^{6}$ K. M. Davey, A. Liefooghe, Critical research and analysis in organizations, [w:] Essential Guide to Qualitative Methods in Organizational Research, ed. by C. Cassell, G. Symon, London 2004, pp. 242-250.

${ }^{7}$ M. Cieślarczyk, Społeczeństwa i społeczności na przełomie wieków - od bezpieczeństwa kultury do kultury bezpieczeństwa, [w:] Bezpieczeństwo w perspektywie socjologicznej. Materiały 37 grupy roboczej XI ogólnopolskiego Zjazdu Socjologicznego, Rzeszów-Tyczyn 2000, pp. 34-38.
} 
and achieving the broadest understood security for the benefit for itself and the environment ${ }^{8}$.

The definition presented above explains the entirety and scope of the concept of safety culture. In this context, it is worth referring to the Yunarmia, often mentioned in this work-paper as a cultural phenomenon, which through its ideological and organizational nature is an integral element of the defence of the Russian state.

At the beginning of this article, a situation emerged which took shape on the international arena after the collapse of the Soviet Union. The purpose of this retrospective was to show the context in which modern Russian statehood developed. The processes taking place in the 1990s are also directly reflected today. Actually, Yunarmia is a product of the Russian ideological and cultural transformation. The idea of a military youth movement dates back to the times of the Soviet Union. At that time, there was a sports and preparatory organization "Ready for work and defence". Nevertheless, in 1990 the National Youth Movement was established, whose activity consisted in the organization of military-sports games "Zarnitsa", "Orlenok", or "Gaydarowiets". What's more, the members of this movement were guarded by the eternal fire, which is a symbol of the memory of soldiers who died during World War II, and organized military-patriotic clubs, such as "Young Borderlander" or "Zorgiency"9.

Yunarmia began its formal functioning on 01.09.2016. The initiator of the military establishment of the youth-patriotic organization was Sergey Shoygu, Defence Minister of the Russian Federation. Therefore, the Ministry of National Defence is the institutional and organizational facilities for the functioning of the Yunarmia. The ministerial protectorate creates conditions in which the members of Yunarmia, compared to the participants of other youth organizations, occupy a sublime social position. Therefore, Yunarmia from the beginning of its creation enjoyed wide support and interest from the Russian society. Possibility to participate in ranks of young Russian patriots have youths between the ages of 11 to 18 . The matter concerning the age of the participants in ranks of Yunarmia is now very widely commented on by the Russian media and the environments related to the protection of children's rights. In a situation when the upper limit is 18 years, and reaching it means an automatic exclusion from the ranks of the Yunarmia, the lower age limit,

${ }^{8}$ Idem, Teoretyczne $i$ metodologiczne podstawy badania problemów bezpieczeństwa i obronności państwa, Siedlce 2009, pp. 153-154.

9 A. Anushevskaya, Chto takoye dvizheniye „Yunarmia” $i$ zachem ono nuzhno? „Agrumenty i Fakty”, 4.08.2016, pp. 6-8. 
i.e. referring to the entry of the Statute of Yunarmia, is 11 years ${ }^{10}$, is often not respected. It results above all from the particular interests of the Russian authorities, who want to create a powerful and influential youth-patriotic organization that forms the basis for the functioning of Russian military power in the future. At the beginning of 2019, there were almost 350,000 people in the ranks of the Yunarmia. This number, according to the guidelines of the Russian defence ministry, should reach 500,000 by the beginning of May 2019.It is planned that by May $9,2020^{11}$ there would be a million people in the ranks of the Yunarmia. For this purpose, an informal rule was introduced to include children from the age of 7 in organization of young patriots'. Anna Kuznetsova, an ombudsman for children in the Russian Federation, has issued a regulation to all regional ombudsmen regarding the conclusion of an agreement with institutions of Yunarmia, which allows the inclusion of children who have reached the age of 7 in the ranks of this organization. In addition, the scope of the possibility of acquiring new members was also expanded. Currently, in Russia, members of Yunarmia are increasingly becoming foster of children's homes ${ }^{12}$.

Increasing the number of members of the military-patriotic movement has a direct connection with the issue of the security culture of the Russian state. The upbringing of children and young people, which is based on the conviction of the duty to defend their homeland, creates conditions for increasing the defence potential of the state. Despite the wide scope of the definition of security culture presented in this article, the semantic approach to this concept contains a complex structure. The culture of security consists of the sphere of mental culture, the sphere of organizational culture and the sphere of material

${ }^{10}$ Ustav Vserossiyskogo Detsko-Yunosheskogo Voyenno-Patrioticheskogo Obshchestvennogo Dvizheniya „Ynarmiya”, Utverzhden Sletomuchrediteley 28.05.2016, Ministerstvo Oborony Rossiyskoy Federacyy, nr 5/3498, p. 5

${ }^{11}$ 9.05.2020 - the 75th anniversary of the victory in World War II, and therefore is planned the demonstrative celebration of this anniversary. The Russians celebrate the Victory Day on May 9, leaving out some important facts about this event. In the belief of many Russians, on May 9, Soviet soldiers suspended the banner over the Reichstag in Berlin. Despite speculation about this date, the banner over the Reichstag was suspended on 9.05.1945, which is confirmed by a photo taken by Evgeniy Haldiey. It is also important that the Second World War was officially completed on 2.09 .1945 by the signing of an act of unconditional surrender of Japan. This event took place aboard the USS Missouri battleship in the Gulf of Tokyo. Russia, on the other hand, date of 9.05.1945, consider as an end of the Great Patriotic War. In this context, shaped conceptual dissonance concerning the date of the end of World War II.

${ }^{12}$ A. Tarasov, Detstvo - pod ryzhye. Militarizaciyarusskoyzhyzni na marshe. „Yunarmia” prihodit $v$ detdoma, Novaya Gazeta, 15.05.2019, <https://www.novayagazeta.ru/ articles/2019/03/13/79863-detstvo-pod-ruzhie?fbclid=IwAR2BZ1JFOiHxOCmR1jh2 Hr0gojWznL_WVE1h2q-1Bv6JKWLzKItpzo80U8E> (12.04.2019). 
culture $^{13}$. It is worth to analyse the various spheres of security culture in the further part of the article, which would allow to create a comprehensive picture of the contemporary security culture of the Russian Federation based on the military-patriotic education of the youth.

\section{Security culture - the sphere of mental culture}

The mental sphere is the state of the subject's consciousness with its intellectual potential including the state of general knowledge and knowledge strictly related to the area of security ${ }^{14}$.The assumptions on which the functioning of Yunarmia is based are directed firstly towards patriotic education and military preparation. It results mainly from the basic tasks resulting from the Statute of Yunarmia. It is indicated that the basic goal of each member of the military-patriotic movement is personal development consisting in nurturing love towards the Homeland. It is getting to know its history, traditions and national heroes. All these activities must be accompanied by military preparation, because it will allow you to defend your country at any time ${ }^{15}$.

Constructing consciousness is a technique of propaganda known for decades. It primarily involves limiting access to information sources presenting a different reality, which is in opposition to the one that is presented to the majority of society. Young people are an ideal field of action in this context. The pragmatic nature of this kind of behaviour towards their own society is dictated by the ambitions of the Russian Federation to restore the role of the world's power ${ }^{16}$.The contemporary position of Russia within the international arena is a complex phenomenon, and it is worth defining it as a process, because this position is constantly changing. The system of the Russian state, to a large extent omitting the complexity of all phenomena and processes, can be reduced to a simple dependence. Currently, the power of Russia is based on energy resources, military potential and special services, the essence of which is derived from the system at the time. It follows that Yunarmia, or youth raised in the military-patriotic spirit, is an integral element of this dependence, especially considering the latter aspect - military potential. The justification for this claim boils down to two factors, namely: first, the Yunarmia in this form and at the current level of preparation is a direct defensive measure of the Russian state; secondly, with the age of 18, the majority of Yunarmia's

${ }_{13}^{13}$ M. Cieślarczyk, op. cit., pp. 157-158.

${ }^{14}$ R. Rosa, Filozofia bezpieczeństwa, Warszawa 1995, p. 46.

15 A. Kolesnikov, Parad ,Yunarmii”: zachem Kremlu marsheruyushchiyeshkolniki, Forbes, 10.05.2017, <https://www.forbes.ru/biznes/344025-parad-yunarmii-zachemkremlyu-marshiruyushchie-shkolniki> (24.04.2019).

${ }^{16}$ J. Bugajski, Cold Peace: Russia's New Imperialism, Westport 2004, pp. 13-16. 
participants plans a professional military career, i.e. they will continue to be the core of the military potential of the Russian Federation.

Patriotic youth education takes place not only by presenting Russia as a unique country against others who do not have such a rich and heroic history or do not have such outstanding scientists, inventors and athletes. The highlights of these values are meetings with Russian athletes, politicians and military. In this way, the spirit of patriotism and civic attitude towards their own state are being built.

The non-reflective absorption of information that is presented to the members of Yunarmia is caused by the skilfully conducted information policy of the Russian Federation. Interesting in this context is the analysis of an official film that promotes Yunarmia and encourages young people to join its ranks. It is worth paying attention to several aspects contained in this film, namely - geographical, historical and cultural.

The geographical aspect is that the map of the Russian Federation presented at the beginning covers not only the Russian territory, but also the area of Armenia, Georgia, Azerbaijan, the eastern part of Ukraine and Belarus, part of Estonia and Finland. Demonstrative nature of disrupting geographical awareness of the space of your country is an inherent element of propaganda, whose main goal is to provoke the sense of uniqueness and the sense of your own power.

The historical aspect consists in presenting the Russians as a nation that has been waging war with the surrounding countries for over 700 years. Among the nations that attacked Russia we can mention e.g. Tatars, Poles, Turks, French and Germans. This treatment builds a sense of potential threat from the rivals of the Russian Federation in the international arena. Particular importance in the context of historical memory is World War II with the most important battles, including battles in Sevastopol or in Stalingrad. The Great Patriotic War is presented as an event in which the Red Army played a major role, and the Ukrainian, Polish, Belarusian, Georgian, American and English soldiers are neglected.

The cultural aspect is primarily a reference to scientific and sport achievements. The film mentions such people as: Yuri Gagarin and his first flight into space, Leonid Kupriyanov - the creator of the telephone set and Alexey Pazhytnov an inventor of the electronic games for children.

Also recalled the Hermitage, which was created on the initiative of Empress Catherine II, and constitutes an element of the national heritage of the Russian Federation. It is a place where numerous works of art by Russian artists and creators are gathered ${ }^{17}$.

17 AgiatacyonnyyrolikVserossiyskogovoyenno-patrioticheskogodvizheniya "Yunarmiya", 3.01.2017, <https://www.youtube.com/watch?v=ZBPDap8oWws> (2.04.2019). 
The content mentioned above shows that the Russian Federation brings up a generation of young people who will be convinced of their own uniqueness and a sense of duty to defend their own country. This is undoubtedly included in the theoretical convention of the state security culture, which Russia now treats as one of the most priority goals of its internal policy.

\section{Security culture - the sphere of organizational culture}

The sphere of organizational culture consists in defining legal regulations, principles and norms, or in other words, ways of achieving value. It also includes the organizational structure and rules of its operation ${ }^{18}$.

The theoretical justification for the security culture in its organizational aspect presented in this way allows the analysis of the organizational structure of the Yunarmia. Indeed, specific elements are indicated, which will be discussed in the further part of this article. Thus, they can be divided into directly referring to the principles and norms of the functioning of the Yunarmia and intermediaries, which form the ideological and legal basis for the functioning of the young patriots movement.

The first group refers primarily to the Statute of the all-Russia youth military-patriotic Yunarmia movement. The provisions contained in it directly refer to the rules, norms and rules of conduct of its members. In addition, this document contains a description of the organizational structure of the militarypatriotic movement. It is indicated that the organs of the Yunarmia are the AllRussian Rally of the Yunarmia, the General Staff, the Central Control and Supervisory Commission and the regional Yunarmia units ${ }^{19}$.

Most of the decisions regarding the most important matters are formally taken up on all-Russia gatherings of young patriots. They are being held at least every 5 years. The members of the General Staff in Moscow and the other organizational units of the Yunarmia are elected. At the first Yunarmia Rally held on 28 May 2016 in the Patriot park in Kubinka near Moscow, decisive provisions regarding the rules and functioning of the Yunarmia were made. The General Commander-in-Chief of the General Staff, the Olympic champion Dmitry Trunenkov, was also elected ${ }^{20}$. An interesting fact in the context of the organizational structure is the fact that representatives of the Ministry of National Defence of the Russian Federation take part in meetings of regional

\footnotetext{
${ }^{18}$ M. Cieślarczyk, op. cit., p. 159.

${ }^{19}$ Ustav Vserossiyskogo Detsko-Yunosheskogo Voyenno-Patrioticheskogo Obshchestvennogo Dvizheniya „Ynarmiya”, Utverzhden Sletomuchrediteley 28.05.2016, Ministerstvo Oborony Rossiyskoy Federacyy, nr 5/3498, p. 6.

${ }^{20}$ Yunarmiya Rossii: dla chegovozrodilos' vserossiyskoyevoyenno-patrioticheskoye dvizheniye, TASS, 22.02.2018, <https://tass.ru/armiya-i-opk/3577097?fbclid=IwAR1MyX U8cZk60WtISNosinHIwwar10fjRjQWjXeHTp0Wef_E5UdtpC1uspE> (14.03.2019).
} 
units, or representatives of the Voluntary Assembly of the United Army, Aviation and Navy or the Central Army Sport Committee.

The range of the Yunarmia is not limited only to the territory of the Russian Federation. Regional centres are also open in the territory of other countries, such as Armenia, Georgia or Azerbaijan. The regional centre of Yunarmia functioning in the territory of the annexed Crimea may seem interesting in this context. Patriotic education and attachment to his homeland in the Crimean Peninsula is characterized by a specific attitude towards the Russian state. It manifests itself through demonstrative display of its attachment to the Russian Federation and Russian culture ${ }^{21}$. Crimea is a place where there is a much greater need for interference by Russian authorities and military, who with their authority strengthen the space of patriotic attitude to the Russian Federation of the younger generation inhabiting the Crimean Peninsula.

It is also worth noting that the branches of Yunarmia are present in the territory of the United States of America. They function essentially at the diplomatic missions of the Russian Federation. This is undoubtedly a demonstrative manifestation of Russian intentions in the affairs of the state, which is treated by the Russian state ideology as the largest rival in the international arena ${ }^{22}$.

The second group, constituting the ideological and legal basis for the functioning of the organization of young patriots, are resolutions of the Russian authorities having a national character. One of them is the National Security Strategy of the Russian Federation until 2020, approved by Russian President Vladimir Putin on May 12, 2009. The provisions contained therein regarding the potential threat to the state constitute a platform on which the narrative is shaped, then reaching the members of the Yunarmia. In addition, the Strategy includes a point related to the defence and military capabilities of the Russian Federation, taking into account, inter alia, the population potential. The implication of these provisions is the reference to the main principles of the functioning of the Yunarmia, i.e. the education of youth in the spirit of patriotism and the preparation for the defence of their own Homeland ${ }^{23}$.

\footnotetext{
${ }^{21}$ Yunarmiya. My - deti Krymskoyvesny Krymskiy Federalnyy Universitetim V. I. Vernadskogo, 15.03.2019, <https://cfuv.ru/news/yunarmiya-my-deti-krymskojj-vesny? fbclid=IwAR26oJ_a8CCKo1u0oUNmKJHc0pRQntCuPAn7c8pgmy0L-

kq_uUzOPD60CRc> (3.04.2019).

${ }^{22}$ I. Katkova, V USA poyavil sya otryad obshchestvennogo dvizheniya "Yunarmiya", Molodezhnoe Informacyonnoye Agenstwo "Mir", 12.01.2019, <миамир.pф/obschestvo/ 44837> (21.04.2019).

${ }^{23}$ Strategiya nacyonalnoy bezopasnosti Rossiyskoy Federacyi do 2020 goda, Utverzhdena Ukazom Prezidenta Rossiyskoy Federacyi ot 12 maya 2009 goda nr 537, <https://web.archive.org/web/20110413220845/http://www.scrf.gov.ru/documents/99.html $>$ (3.04.2019).
} 
The implementation of the decisions of the Russian authorities on the platform of the functioning of the Yunarmia is on the one hand an exemplification of the importance of patriotic youth education in the context of national defence and on the other hand, it shapes the ideological and conceptual pillar of the activities of Yunarmia.

\section{Security culture - the sphere of material culture}

The Minister of National Defence of the Russian Federation, Sergey Shoygu, at the first Yunarmia Rally in 2016 gave a speech during which he pointed out that the purpose of Yunarmia was to bring up healthy, patriotic citizens of the Russian state. It is a reference to the intangible sphere of security culture. Nevertheless, it is worth noting that Yunarmia, as an element of the defence potential of the state, is a tool in the form prepared for leading and participating in military activities of the youth. From this point of view, referring to theoretical justifications, it can be assumed that Yunarmia is a personal base of the Russian army, and thus it is a sphere of human resources used when necessary in processes ensuring the security of the state.

The theoretical premise boils down to the conclusion that material culture includes techniques and technologies, infrastructure, equipment, technical and financial tools. In the case of Yunarmia, the context of material culture should be considered through the prism of the armament potential of the Russian army. This is due to the fact that Yunarmia is directly connected with the Ministry of National Defence of Russia, and therefore the aspect of material culture should be implemented in the material culture of the Russian army.

Sergey Shoygu, on the occasion of the first Yunarmia' Rally, mentioned also the scope of preparatory youth preparation. He emphasized that they would be given the opportunity not only to participate in actual military training taking place on the training grounds, but also to be their direct participants. To this end, an organizational and preparatory state structure was created, whose primary purpose is to provide the Yunarmia with material resources - military costumes, specially prepared weapons and techniques that will be used in the training process of the members of Yunarmia.

An example of this type of activity is carried out on the territory of the Kostromskoy Military Training Center Marshal of the Soviet Union S. K. Timoshenko tactical game "Stalker". Its main task was to eliminate an opponent who was in a protected fortress. For this purpose, military technical tools enabling the tracking of your opponent were made available to participants of the game. In addition, a part of the training was also 
the presentation of new achievements of Russian scientists in the field of armaments ${ }^{24}$.

The scope of the material culture of the Yunarmia presented above is a clear example that the activities of the Russian Federation are directed at the development of this youth-patriotic movement, which in the future will be a decisive factor in the military potential of Russia. The opportunity to participate in military training and communing with real armaments technology and tools creates a development platform for the defense capabilities of the Russian Federation.

\section{Conclusions}

According to the ranking of the strongest armies in the world presented by Global Fire Power, in 2018 the Russian Federation was in the second place. The total number of soldiers, taking into account active and reserve resources, accounted for over 3.5 million people. On a global scale, this is one of the highest indicators determining the capabilities and military potential of the Russian Federation $^{25}$.

This article presents one of the processes of increasing the military capabilities of the Russian state. After the collapse of the Soviet Union and a decade of relative weakness, the Russian Federation has returned to the path of rebuilding its own power and position of the world power ${ }^{26}$. To this end, the Russian authorities, in addition to the economic issue, based on trade in energy resources, focused their efforts on the idea of building a citizen's model, which is patriotically oriented towards his homeland and, on the other, is well prepared to defend his country. The realization of these intentions was the establishment in 2016 of the military youth-patriotic Yunarmia movement. The basic task of this organization is to educate Russian youth in terms of defensive adaptation, which is based on the patriotic idea of attachment to their state and nation.

The phenomenon of Yunarmia in the above considerations has been implemented in the cultural context, and more specifically in the context of the security culture of the Russian Federation, which is currently the subject

24 Luchshyyeyunarmieycy na voyenizirovanoyestafiete ,Stalker” - komanda kostromskoyoblasti, GlavnyyShtabYunarmii, 31.07.2018, <https://yunarmy.ru/news/ 2679?fbclid=IwAR19cefFXXltPsmOAvU_OVW6kjYwSag8jikw7cMrhVWAoOIpxmap8L -tCio> (6.04.2019).

${ }^{25}$ Russia Military Strength, <https://www.globalfirepower.com/country-military-strengthdetail.asp?country_id=russia\&fbclid=IwAR1-DLiN5tcfYzN3tzXZ10m1AUE9vfjke D4ZqLb3zLdXINrKe7zvEBgMUuk\#manpower> (2.04.2019).

26 M. Olchawa, Imperialna rozgrywka. Ukraina $w$ geopolitycznej strategii Stanów Zjednoczonych, Kraków 2009, pp. 13-15. 
of interest of many research centres around the world. Yunarmia is a cultural phenomenon within the Russian state. It is a result of the popularity of this organization in contemporary Russia and the narrative that is shaped around it. The operation of the Yunarmia is widely commented on practically in all Russian mass media. In this context, one should speak about the process of shaping the "yunarmia's" culture. The most important fact proving its popularity is primarily the number of members, which is growing rapidly from month to month, because it is planned that by 2020 there will have been around one million young people in the ranks of Yunarmia.

The Russian Federation, realizing its policy on the international arena, undoubtedly takes into account the fact that the preservation of the superpower position requires the improvement of its military potential. Therefore, by creating a specific cultural construct based on military-patriotic principles, the Russian state creates a sphere of human resources that give additional strengths in the context of the fight for primacy on the world stage. Yunarmia through appropriate military-defensive preparation is an inseparable element of the military system of the Russian Federation. As a result of a skilfully conducted policy of cultural and military socialization, Russia has achieved unprecedented success. Therefore, in the future conducting various kinds of agonizing about the military and defence potential of the Russian Federation, a strong emphasis should be put on and take into account in this context the military-patriotic organization Yunarmia as an integral element of the Russian defence system.

\section{BIBLIOGRAPHY:}

$\checkmark$ Agiatacyonnyy rolik Vserossiysko govoyenno-patrioticheskogo dvizheniya "Yunarmiya", 3.01.2017, <https://www.youtube.com/watch?v=ZBPDap8oWws>

$\checkmark$ Anushevskaya A., Chto takoye dvizheniye „Yunarmia” $i$ zachem ono nuzhno?,„Agrumenty i Fakty”, 4.08.2016

$\checkmark$ Bugajski J., Cold Peace: Russia's New Imperialism, Westport 2004

$\checkmark$ Cieślarczyk M., Społeczeństwa i społeczności na przełomie wieków - od bezpieczeństwa kultury do kultury bezpieczeństwa, [w:] Bezpieczeństwo w perspektywie socjologicznej. Materiaty 37 grupy roboczej XI ogólnopolskiego Zjazdu Socjologicznego, Rzeszów-Tyczyn 2000

$\checkmark$ Cieślarczyk M., Teoretyczne i metodologiczne podstawy badania problemów bezpieczeństwa i obronności państwa, Siedlce 2009

$\checkmark$ Davey K. M., Liefooghe A., Critical research and analysis in organizations, [w:] Essential Guide to Qualitative Methods in Organizational Research, ed. by C. Cassell, G. Symon, London 2004

$\checkmark$ Kagan R., Powrót historii i koniec marzeń, Poznań 2010 
$\checkmark$ Katkova I, V USA poyavilsya otryad obshchestvennogo dvizheniya "Yunarmiya", Molodezhnoe Informacyonnoye Agenstwo "Mir", 12.01.2019, <миамир.pф/obschestvo/44837>

$\checkmark$ Kolesnikov A., Parad „Y Yunarmii”: zachem Kremlu marsheruyushchiye shkolniki, <https://www.forbes.ru/biznes/344025-parad-yunarmii-zachemkremlyu-marshiruyushchie-shkolniki>

$\checkmark$ Luchshyye yunarmieycy na voyenizirovanoy estafiete „Stalker” - komanda kostromskoy oblasti, Glavnyy Shtab Yunarmii, 31.07.2018, <https://yunarmy.ru/ news/2679?fbclid=IwAR19cefFXXltPsmOAvU_OVW6kjYwSag8jikw7cMrh VWAoOIpxmap8L-tCio>

$\checkmark$ Olchawa M., Imperialna rozgrywka. Ukraina $w$ geopolitycznej strategii Stanów Zjednoczonych, Kraków 2009

$\checkmark$ Rosa R., Filozofia bezpieczeństwa, Warszawa 1995

$\checkmark$ Russia Military Strength, <https://www.globalfirepower.com/countrymilitary-strength-detail.asp?country_id=russia\&fbclid=IwAR1-DLiN5tcfY zN3tzXZ10m1AUE9vfjkeD4ZqLb3zLdXINrKe7zvEBgMUuk\#manpower>

$\checkmark$ Stefanowicz J., Przedmowa, [w:] Współczesne pojmowanie bezpieczeństwa, red. J. Stańczyk, Warszawa 1996

$\checkmark$ Strategiya nacyonalnoy bezopasnosti Rossiyskoy Federacyi do 2020 goda, Utverzhdena Ukazom Prezidenta Rossiyskoy Federacyi ot 12 maya 2009 goda nr 537, <https://web.archive.org/web/20110413220845/http://www.scrf.gov.ru/ documents/99.html $>$

$\checkmark$ Tarasov A., Detstvo - pod ryzhye. Militarizaciyarusskoyzhyzninamarshe. „Yunarmia” prihodit $v$ detdoma,

<https://www.novayagazeta.ru/articles/2019/03/13/79863-detstvo-podruzhie?fbclid=IwAR2BZ1JFOiHxOCmR1jh2Hr0gojWznL_WVE1h2q1Bv6JKWLzKItpzo80U8E >

$\checkmark$ Ustav Vserossiyskogo Detsko-Yunosheskogo Voyenno-Patrioticheskogo Obshchestvennogo Dvizheniya ,, Ynarmiya”, Utverzhden Sletomuchrediteley 28.05.2016, Ministerstvo Oborony Rossiyskoy Federacyy, nr 5/3498

$\checkmark$ Yunarmiya. My - detiKrymskoyvesny, KrymskiyFederalnyyUniversitetim. V. I. Vernadskogo, <https://cfuv.ru/news/yunarmiya-my-deti-krymskojjvesny?fbclid=IwAR26oJ_a8CCKo1u0oUNmKJHc0pRQntCuPAn7c8pgm y0L-kq_uUzOPD60CRc>

$\checkmark$ YunarmiyaRossii: dlachegovozrodilos' vserossiyskoye voyenno-patrioticheskoye dvizheniye, <https://tass.ru/armiya-i-opk/3577097?fbclid= IwAR1MyXU8cZk60WtISNosinHIwwar10fjRjQWjXeHTp0Wef_E5UdtpCluspE>

$\checkmark$ Zakaria F., Koniec hegemonii Ameryki, Warszawa 2009 